\title{
Research on Schooling Characteristics of Local Higher Colleges and Universities under the Strategic Background of Strong Province in Higher Education
}

\author{
Chengjun Shen \\ Jilin Agricultural University, Changchun China, 130118
}

Keywords: Strong province in higher education; Local higher colleges and universities; Schooling characteristics

\begin{abstract}
This article mainly expounds the strategy of strong province in higher education under the new situation and local higher colleges how to highlight the schooling characteristics under this situation and explores the scientist schooling path of local colleges and universities servicing regional economic and social development. It has practical guiding value in establishing school running orientation, improving and perfecting educational function, organizing and implementing activities of talent training and teaching and researching. It can enrich schooling characteristics in higher colleges and universities, develop the related theory in the field of education and economic system and provide guidance for the local colleges and universities in taking the path of development characteristics of running a school in theory.
\end{abstract}

\section{The Research Status at Home and Abroad}

Research Status Abroad. In the long-term process of running a school, Local colleges and universities in the United States format the features of service for the society: first, adhere to the service for regional development. First of all, the school-running thoughts and purpose root in regional characteristics, consider the development of the regions current and long-term interests, serve for the regional development. Secondly, set professional basing on the region's development needs, adjust and rich their own service content timely and provide intellectual support for regional economic development. The state provides funding support for the school. Again, schools open various types of facilities to serve for the region's public and social. Second, extensive cooperation with all walks of life. System of local colleges and universities in the United States all set the board of directors, which is appointed by the governor-general and is composed of the influential people from all walks of life. According to the needs of local economic and social development, the board of directors reviews the affairs of colleges and universities and makes decisions. Colleges and universities also actively take part in the local economic development, cooperate with local government and enterprise actively and realize win-win situation with local development. The education philosophy of serving the local economic and social development, represented by the University of Wisconsin's, has had a profound impact to the world of higher education. It marks the United States produces the social service function of the colleges and universities firstly. Since 1990s, the Canadian government cut funds for education in colleges and universities at all levels. The local universities actively play their own advantages, cooperate with enterprises, scientific research departments, develop the characteristics of "industry-university-institute" cooperation and greatly enhances the scientific research ability of technology innovation. Such as developing cooperation education positively with social, mobilizing social forces and institutions to cooperate with higher education in conduct joint training university students. German local university is composed of higher professional colleges, which is famous in facing society, strong technology applicability and shorter educational system. From essence, it is designed for industries and enterprises. Colleges and universities are to cultivate applied talents. Higher professional schools and small and medium enterprises are a natural partnership and form the characteristic about co-operative through a variety of ways.

The Domestic Research Status. Our country established two strategic targets, strong country in human resources and creative country, and put forward "to speed up from a higher education power towards the great higher education powers". According to incomplete statistics, 
provinces, which put forward the construction of strong province in higher education, include Guangdong, Zhejiang, Shandong, Shanxi, Liaoning, Heilongjiang, Hubei, Anhui, etc. by the end of 2012.

In recent years, some areas have put forward the goal of power province in higher education and study its connotation deeply. Mainly study the connotation of higher education strong province, the provincial higher education strong province strategy research. Mainly concentrate in attaching great importance on the innovation system mechanism, stimulate the development of vitality, optimize the structure of higher education, and realize the coordinated development. Attached great importance to the construction of high-level university, play to the leading driving effects. Attention in order to improve the quality as the core, the restructuring to provide talent support for transfer way. Attached great importance to strengthen the higher vocational education, construct the high skill talented person growth "overpass". Attached great importance on the building discipline innovation platform, improve the ability of serving local development. Attached great importance on the construction of teacher team, implement the strategy of talent strong teaching.

July 1, 2013, Jilin province issued the file of the Jilin provincial party committee of the communist party of China, Jilin province people's government on the opinions of the construction of higher education strong province "( $\mathrm{Ji}$ [2013] 10). Put forward positive transformation of the mode of development of higher education and take the road of connotative development road with quality improvement as the core. Form the modern higher education system with characteristics of reasonable layout structure, the optimization of subjects and apply as the core.

In terms of school-running characteristics, the country issued relevant documents to guide higher colleges in planning the characteristics rationally and scientifically many times. The file issued in 2010, a trial basis the national medium and long-term education reform and development plan outline (2010-2020), pointed out that to ensure the development of higher education science and education quality steadily improve the structure of higher education must be optimized and have the characteristics. Set up special funds, support local higher education so as to promote the characteristic construction of colleges and universities. Further pointed out that to gradually establish a classification system of colleges and universities and the categorized management. Government will also play a role of policy guidance for the allocation of resources, guide the various colleges and universities to carry on the reasonable localization, avoid homogeneity tendency and make the universities gradually form their own school-running style in the field of different levels and characteristics. March 16, 2012, the ministry of education promulgated the several opinions on comprehensively improving the quality of higher education by ministry of education. It pointed out that colleges and universities should have a characteristic to establish the classification system in colleges and universities and overcome the homogeneity tendency. These policy documents for the development of local college characteristics have pointed out the direction of the road.

Domestic scholars have taken more research on both theory and practice of school-running features in colleges and universities. Some scholars theoretically probes into the characteristics of colleges and universities, what colleges do and how to handle the problem of the colleges and universities. Problems involved the core issue including school-running orientation, concept and talent training, etc., such as Xiao Hai-Tao's "theory connotation and characteristics of university characteristics", Dai Jiliang's "the higher education schools implement characteristics of path choice", Zhong Jinsong's "the restricting factors for the construction of school-running features in colleges and universities and the countermeasure analysis", etc.. These theoretical research have great significance to inherit, enrich and further construction of local university characteristics theory system. Some researchers used the method of case analysis and investigation to analyze the practice of school-running features in colleges and universities and discuss the formation and development of school characteristics in order to better guide the 
construction of school running characteristics of colleges and universities, such as Wang lian-sen's "the university characteristic strategic direction choice: instance and enlightenment ", Zhang ning-sheng's "the characteristics development - the inevitability of strong road", Guo guang-sheng's "region roundup of school running characteristics of institutions of higher learning in Beijing". Some scholars sums up the features of higher education in the formation of path and its significance from theory and practice, which is improving the quality of higher education of school running characteristics. They consider that the schooling characteristic is the objective demand of higher education power and is the inevitable requirement of colleges and universities to obtain sustainable development. But there is rarely research seen in local colleges contacted with schooling characteristics and the regional economic development.

\section{Formation of Schooling Characteristic and Its Function in Running Universities in Jilin Province}

A regional economic development relies on education, especially higher education. The road of running characteristic school is not only the university itself keep the vigor and vitality but also realize the inevitable choice of sustainable development. And it is the inevitable requirement of constructing the strong province of higher education.

Highlight the Characteristics of the School. Universities in Jilin province will build classification management system to guide the reasonable transformation of colleges and universities, clear development orientation, overcome the homogeneity tendency and have the characteristics in the field of different levels. "985" and "211" universities show the features of research. General colleges and universities show the features of applied undergraduate colleges. The vocational colleges show the features of skilled technology. Higher education in national regions, special higher education and higher vocational and technical teacher education school improve strength and speed up the characteristic development. Provincial department of colleges and universities to build and promote the university and the central ministries and commissions, research institutes, industry enterprises, cities and counties in the government cooperation, enhance the competitive advantage, form new features.

We should take culture construction in university as the outstanding tasks for the development of characteristic, promote the campus culture, regional culture and the organic combination of talents cultivation, encourage independent thinking, good atmosphere of free exploration, innovation, concise and cultivate the spirit. Each college has its own characteristics in the university. Perfect the provincial key universities, provincial demonstration college dynamic management mechanism.

Highlight the Characteristics of Professional Disciplines. Professional disciplines of universities will be in accordance with the "choose the need, choose the merit, and choose the characteristic" to promote the construction of key discipline as a whole and come into contact with the pillar, advantages, characteristics and strategic emerging industries in jilin province. Take the provincial level key disciplines as Jilin province key construction. Foster national key disciplines and build strong influence of Jilin professional brand. Give full play to the demonstration effect of national and provincial key disciplines and professional brand to promote interdisciplinary professional to speed up the construction and development.

\section{References}

[1] Lu Lianjun. The construction of strong province in higher education and schooling characteristics of colleges and universities [J]. Heilongjiang Education(Higher Education Research \& Appraisal), 2006.06

[2] Zheng Jing. Characteristics of Adults Higher Education Based on the Quality [J]Sichuan University of Arts and Science Journal, 2009.03. 
[3] Wang Zhan, Set up and carry out the scientific concept of development and strive to build a strong province in higher education [J], Jiangsu Higher Education, 2004.06.

[4] Wang JinYao. Research on theories of strong province in higher education [J], China Higher Education Research, 2002.7.

[5] Xu Siliang. On characteristics in running higher education institutions [J], Journal of Higher Education, 2001.06.

[6] Ding Xiaochang. Constructing Advanced Province in Higher Education: Leading by Culture Innovation [J]. Research in Educational Development, 2013, 2.

[7] Zhang Shaojie. Strategy research on strong province of function and development in higher education [J]. Heilongjiang Researches on Higher Education,,2009,1

[8] Liu Xian-jun. My Views of the Construction of Powerful Higher Education Province in Hunan [J]. University Education Science, 2010, 6.

[9] LU Lian_jun. The Denotations and Realization of Constructing a Province with a Powerful Higher Education [J]. Journal of Nanjing University of Aeronautics \& Astronautics (Social Sciences), 2006, 12.

[10] Shen Jian. Some thinking about us will accelerate the development of Jiangsu higher education strong province [J]. Jiangsu Higher Education, 2008, 11. 